(6) OPEN ACCESS

\title{
Biosimilar infliximab use in paediatric IBD
}

\author{
Lisa Richmond, ${ }^{1}$ Lee Curtis, ${ }^{1}$ Victoria Garrick, ${ }^{1}$ Pam Rogers, ${ }^{2}$
} Michelle Wilson, ${ }^{3}$ Rachel Tayler, ${ }^{1}$ Paul Henderson, ${ }^{2,3}$ Richard Hansen, ${ }^{1}$ David C Wilson, ${ }^{3}$ Richard K Russell ${ }^{1}$

${ }^{1}$ Department of Paediatric Gastroenterology, Royal Hospital for Children, Glasgow, UK

${ }^{2}$ Department of Paediatric Gastroenterology, Royal Hospital for Sick Children, Edinburgh, UK

${ }^{3}$ Child Life and Health, University of Edinburgh, Edinburgh, UK

\section{Correspondence to} Lisa Richmond, Paediatric Clinical Research Facility, Neurosciences building, Queen Elizabeth University Hospital, Glasgow G51 4TF, UK; lisa.richmond@nhs.net

Received 16 May 2017 Revised 26 August 2017 Accepted 6 September 2017

Published Online First

7 October 2017

\section{CrossMark}

To cite: Richmond L, Curtis L, Garrick V, et al. Arch Dis Child 2018;103:89-91.

\section{ABSTRACT}

Background Biosimilar infliximab became available in the UK in 2015. Paediatric experience to date on its use is limited. We prospectively evaluated the safety and efficacy of biosimilar infliximab (Remsima) in two paediatric gastroenterology networks in patients with inflammatory bowel disease.

Methods Prospective clinical data were collected from laboratory reports, electronic patient records and case notes of 40 patients starting Remsima for the first time. Disease activity scores together with blood and stool biomarkers were used to assess response.

Results Our data set highlights that Remsima was associated with a significant clinical and biochemical improvement $(p<0.01$ or less for all parameters assessed) in Crohn's disease post induction. There were no significant safety issues noted. The total cost saving was $€ 47800$, representing a $38 \%$ reduction from originator.

Conclusion We found that biosimilar infliximab is as effective as originator infliximab and its use is associated with significant cost savings.

\section{INTRODUCTION}

There are an increasing number of patients with paediatric inflammatory bowel disease (PIBD) commencing antitumour necrosis factor (TNF) therapy in the form of infliximab. ${ }^{1}$ Infliximab is commonly used in PIBD for chronically active disease, which is not controlled by 'conventional' therapy, fistulising perianal Crohn's disease (CD) or for acute severe colitis as an alternative to colectomy. ${ }^{2}$ Initial PIBD use was limited due to the lack of a specific paediatric licence for Remicade, its significant cost and the potential safety profile, specifically malignancy.

In early 2015, European Medicine Agency licence approval was granted for biosimilar infliximab use in PIBD from initial studies in adults with rheumatological conditions. Biosimilar infliximab is available for use in the UK either as Remsima or Inflectra. Since the initial studies satisfying the criteria for biosimilarity are in adult rheumatology and did not use standard inflammatory bowel disease dosing strategies, an urgent need developed for PIBD-specific data, focusing both on safety and clinical effectiveness.

There is also the added opportunity for significant cost savings, which may in turn allow easier access to therapy. A prospective safety, efficacy and cost-effectiveness evaluation of biosimilar infliximab (Remsima) was carried out in two paediatric gastroenterology networks between 2015 and 2016.

\section{PATIENTS AND METHODS}

All patients with PIBD from the regional services in the West and South East of Scotland (based at the Royal Hospital for Children, Glasgow, and the Royal Hospital for Sick Children, Edinburgh) who required infliximab were started on Remsima. Data were collected at treatment initiation and response reviewed, following three induction doses, at around week 12 post initiation. In line with the licence, standard dosing at $5 \mathrm{mg} / \mathrm{kg}$ at 0,2 and 6 weeks was used with infusions given over 2 hours. Patients were routinely given hydrocortisone at $4 \mathrm{mg} / \mathrm{kg}$ (maximum dose $200 \mathrm{mg}$ ) prior to each Remsima infusion. No consistent phial sharing protocols were used for the duration of this evaluation. Prospective clinical data were collected from local laboratory reports, electronic patient records and case notes of patients starting Remsima. Our intention was that all patients were anti-TNF-naïve at initiation.

Clinical disease activity indices, namely the weighted Paediatric Crohn's Disease Activity Index ${ }^{3}$ and Paediatric Ulcerative Colitis Activity Index, ${ }^{4}$ were used to document disease activity at initiation and follow-up. For analysis purposes, calprotectin samples and $\mathrm{C}$ reactive protein values were limited to laboratory-reported maximum and minimum assay values $(>1800 \mu \mathrm{g} / \mathrm{g}$ and $<1 \mathrm{mg} / \mathrm{L}$, respectively). An adequate infliximab trough was deemed to be in the range of $3-7 \mathrm{mg} / \mathrm{L}$. Levels and antibodies were measured routinely and were not dependent on clinical status.

Data were expressed as median with range. Statistics were calculated using Microsoft Excel (Microsoft Corporation, Redmond, Washington, USA) and GraphPad V.3 software (GraphPad Software, La Jolla, California, USA). Ethical approval was not required as this was an evaluation of clinical practice. Average costings for a phial of biosimilar and originator infliximab (Remsima and Remicade, respectively) were obtained from the recent award of a national framework agreement by National Procurement Scotland (OJEU, contract award notice: http://ted.europa.eu/udl?uri=TED: NOTICE:92352-2015:TEXT:EN:HTML). The cost saving was then calculated by adding the total number of phials used and calculating the cost saving on each phial multiplied by this difference.

\section{RESULTS}

Forty consecutive patients $(60 \%$ male $)$ started Remsima between August 2015 and June 2016, equating to 190 infusions in total. Twenty-nine patients had $\mathrm{CD}$ and 11 ulcerative colitis (UC)/inflammatory bowel disease unclassified (IBDU). The median age of patients (IQR) at 
Table 1 Characteristics of patients at initiation and 12-week followup

\begin{tabular}{|c|c|c|c|}
\hline Clinical data & At initiation & At 12 -week review & $\begin{array}{l}\text { Comparative } \\
\text { p Value }\end{array}$ \\
\hline ESR, median (IQR) & $16(7.5-31.3)(n=40)$ & $5(2.25-10)(n=26)$ & $p=0.0009$ \\
\hline CRP, median (IQR) & $5.5(2-21.3)(n=40)$ & $1(1-2)(n=27)$ & $p=0.0004$ \\
\hline Albumin, median (IQR) & $35(30.8-38)(n=40)$ & $38(36-41)(n=27)$ & $p=0.002$ \\
\hline $\begin{array}{l}\text { Calprotectin, median } \\
\text { (IQR) }\end{array}$ & $\begin{array}{l}840(618.3-1642.5) \\
(n=34)\end{array}$ & $250(60-760)(n=17)$ & $p=0.008$ \\
\hline wPCDAI, median (IQR) & $27.5(7.5-55)(\mathrm{n}=29)$ & $5(0-20)(n=21)$ & $p=0.002$ \\
\hline PUCAl, median (IQR) & $45(40-55)(n=11)$ & $23.8(8.1-60)(n=6)$ & $\mathrm{p}=0.4$ \\
\hline \multirow{4}{*}{$\begin{array}{l}\text { Disease classification } \\
\text { (Crohn's) } \\
\%(\mathrm{n} / \mathrm{N})\end{array}$} & Remission, 28\% (8/29) & $\begin{array}{l}\text { Remission, 67\% } \\
(14 / 21)\end{array}$ & $\mathrm{p}=0.002$ \\
\hline & Mild, $31 \%(9 / 29)$ & Mild, $28 \%(6 / 21)$ & $\mathrm{p}=0.9$ \\
\hline & Moderate, $28 \%$ (8/29) & Moderate, $0 \%(0 / 21)$ & $p=0.02$ \\
\hline & Severe, $13 \%(4 / 29)$ & Severe, $5 \%(1 / 21)$ & $\mathrm{p}=0.6$ \\
\hline
\end{tabular}

CRP, C reactive protein; PUCAI, Paediatric Ulcerative Colitis Activity Index; WPCDAI, weighted Paediatric Crohn's Disease Activity Index.

diagnosis was 12.7 years (10-14) and 13.7 years (13-16) at Remsima initiation.

The primary reasons for treatment in CD were active luminal disease $76 \%(22 / 29)$, perianal disease $14 \%(4 / 29)$ and with other indications $10 \%(3 / 29)$. For UC/IBDU, chronic refractory disease was the indication in $64 \%(7 / 11)$ and acute severe colitis in $36 \%$ $(4 / 11)$. The majority $(95 \% ; 38 / 40)$ of patients were on coimmunomodulator therapy; $71 \%(27 / 38)$ on azathioprine/mercaptopurine and 29\% (11/38) on methotrexate. All patients received intravenous hydrocortisone pre-Remsima dosing. At initiation $43 \%$ (17/40) were also on oral prednisolone. Remsima was associated with a significant clinical and biochemical improvement in $\mathrm{CD}$ postinduction (table 1). Infliximab levels and antibodies were recorded for 50\% (20/40) of patients following induction (figure 1). The median trough level was $3.85 \mathrm{mg} / \mathrm{L}$ (IQR 1.604.98) and 10/20 (50\%) samples had a level outside the targeted therapeutic range.

Only two patients had positive antibodies recorded, one of whom experienced an acute infusion reaction (AIR). This gives an AIR per infusion rate of $1 / 190(0.5 \%)$ and AIR per patient $1 / 40(2.5 \%)$ from this cohort. Immediately after the second

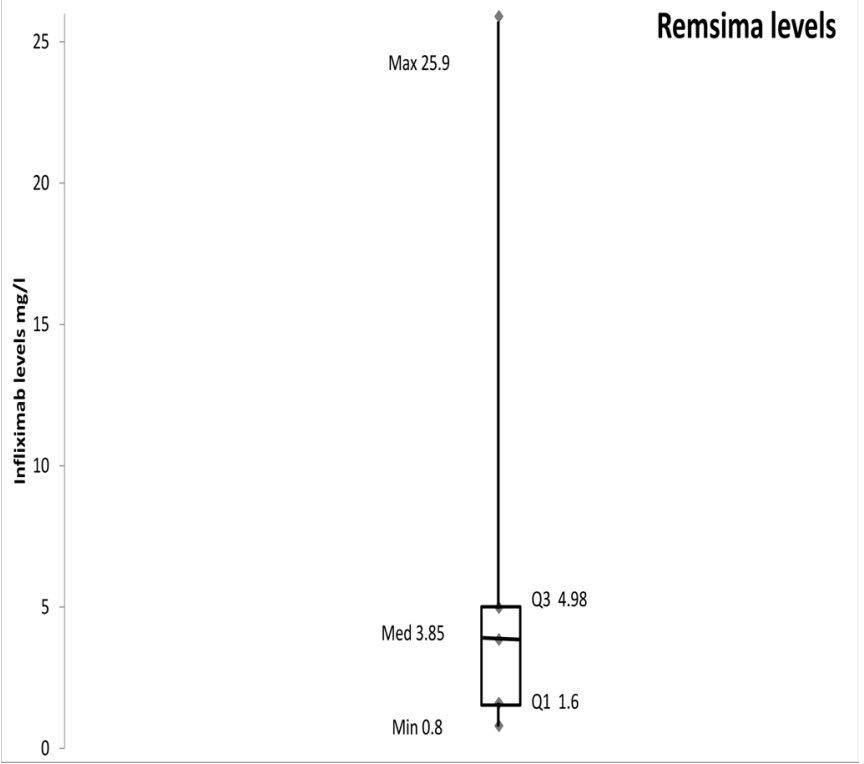

Figure 1 Infliximab levels at week 14 following induction.
Remsima infusion began, the patient's face became flushed and the throat felt tight. The infusion was discontinued and therapy was subsequently changed from Remsima to adalimumab. Infliximab levels on this patient were recorded as $25.9 \mathrm{mg} / \mathrm{L}$ with strongly positive antibodies. This patient had in fact been exposed to Remicade 6 years previously with mild sensitivity. There were no additional safety issues recorded.

The average cost saving per phial during this period was approximately 38\% reduction from the originator (Remicade) to the biosimilar (Remsima). For the total number of infusions carried out during this evaluation, we estimate a conservative cost saving of around $£ 47800$ ( $€ 57000$ ).

\section{DISCUSSION}

The benefits of infliximab treatment for PIBD are well established and represent a cornerstone of PIBD practice for patients with inadequate or lost response to first-line and second-line therapy. Published studies to date have described outcomes using originator infliximab (Remicade). These data have shown that early clinical response and remission rates following an induction course of Remsima match those of historical patients treated with infliximab (Remicade). ${ }^{1}$ To date, there is a paucity of data in the paediatric literature on biosimilar use, with none published from the $\mathrm{UK}^{5}$ and none as robust as the current study, which prospectively collected clinical and laboratory data as part of good clinical practice. Recent guidelines have generally advised caution in the use of biosimilar anti-TNFs until further data on their use have become available ${ }^{6}$; we hope this study will help support their wider introduction into paediatric practice.

Continued close monitoring of these patients is necessary to collect longer term data and to evaluate maintenance of remission, secondary loss of response and safety. The financial benefits of using these treatments are clear from this and other studies, but will only be upheld if long-term maintenance rates match these initial clinical response rates. As the emerging data for treatment-naive patients are published, the logical next step is to look at switching those already established on originator infliximab to biosimilars. Early paediatric data on this are encouraging, but more detailed information on patient outcomes, including trough drug levels and antibodies, is awaited. ${ }^{7}$ The trough level data from this study showed a wide range of values with several below the quoted therapeutic range. Although we attempted to collect these data in all patients, there may be a slight bias in the samples we collected towards patients with signs of limited/no response to infliximab. This may be reflected in the fact that $40 \%$ of the results were subtherapeutic. Importantly there were no signs of significant allergenicity.

In summary, we have demonstrated that biosimilar infliximab is as safe and effective as originator infliximab in the short-term using data from two regional referral centres.

There are also significantly associated cost savings. These baseline data have now enabled us to confidently switch patients from originator to biosimilar, adopting the same prospective methodology to monitor effectiveness, safety and cost.

Acknowledgements Napp Pharmaceuticals provided financial support to help with this audit but did not have any influence on the data collection, analysis or conclusions drawn. RKR is supported by an NHS Research Scotland Senior Fellowship. The IBD team at RHC Glasgow is supported by the Catherine McEwan Foundation and Yorkhill IBD fund. The IBD teams in RHSC Edinburgh and University of Edinburgh are supported by the GI-Nutrition Research Fund, Child Life and Health, University of Edinburgh and the Edinburgh Children's Hospital Charity. RH and PH are supported by a Career Researcher Fellowship from NHS Research Scotland. We are grateful to Nadia Crockett, commodity manager at National Procurement Scotland, for advice on presenting costings related to originator and biosimilar infliximab. 
Competing interests LR: conference fees and travel from Tillotts. VG: conference fees and travel from AbbVie. RT: speaker's fees and conference attendance from Nutricia. PH: lecture fees from Dr Falk. RH: speaker's fees, conference support or consultancy fees from Nutricia, Dr Falk, MSD Immunology and 4D Pharma. DCW: lecture fees, consultancy, travel support from AbbVie; consultancy from Takeda; and financial support for research by MSD. RKR: speaker's fees, travel support and participated in medical board meetings with AbbVie, Napp and Nestle. All other listed authors have no declared conflicts of interest.

Provenance and peer review Not commissioned; externally peer reviewed.

Open Access This is an Open Access article distributed in accordance with the Creative Commons Attribution Non Commercial (CC BY-NC 4.0) license, which permits others to distribute, remix, adapt, build upon this work non-commercially, and license their derivative works on different terms, provided the original work is properly cited and the use is non-commercial. See: http://creativecommons.org/ licenses/by-nc/4.0/

(c) Article author(s) (or their employer(s) unless otherwise stated in the text of the article) 2018. All rights reserved. No commercial use is permitted unless otherwise expressly granted.

\section{REFERENCES}

1 Cameron FL, Wilson ML, Basheer N, et al. Anti-TNF therapy for paediatric IBD: the Scottish national experience. Arch Dis Child 2015;100:399-405.

2 de Bie Cl, Escher JC, de Ridder L. Antitumor necrosis factor treatment for pediatric inflammatory bowel disease. Inflamm Bowel Dis 2012;18:985-1002.

3 Turner D, Griffiths AM, Walters TD, et al. Mathematical weighting of the pediatric Crohn's disease activity index (PCDAI) and comparison with its other short versions. Inflamm Bowel Dis 2012;18:55-62.

4 Turner D, Otley AR, Mack D, et al. Development, validation, and evaluation of a pediatric ulcerative colitis activity index: a prospective multicenter study. Gastroenterology 2007;133:423-32.

5 Sieczkowska J, Jarzębicka D, Banaszkiewicz A, et al. Switching between infliximab originator and biosimilar in paediatric patients with inflammatory bowel disease. preliminary observations. J Crohns Colitis 2016;10:127-32.

6 Danese S, Fiorino G, Raine T, et al. ECCO Position Statement on the Use of Biosimilars for Inflammatory Bowel Disease-An Update. J Crohns Colitis 2017;11:26-34.

7 Cornillie F, Hanauer SB, Diamond RH, et al. Postinduction serum infliximab trough level and decrease of $\mathrm{C}$-reactive protein level are associated with durable sustained response to infliximab: a retrospective analysis of the ACCENT I trial. Gut 2014;63:1721-7. 